\title{
The Institutions-Innovation Dilemma: the Case of Coastal Fisheries
}

\author{
Manuel González-López'
}

\begin{abstract}
This paper explores into the relationship between institutions and innovations at coastal fishing activities. It is said that institutions favor innovation because they give rise to the necessary stability for fluid knowledge exchanges and learning processes. Nevertheless, at the same time, innovation implies breaking or altering routines and behaviors, i.e. to alter institutions. We try to clarify in which conditions existing institutions may foster innovation or, on the contrary, hinder it. For this purpose we have analyzed the case of a natural resource based sector, the coastal fishing sector in Galicia (Spain). Our findings indicate that a given institutional arrangement can give rise at the same time to positive and negative factors affecting innovation. Moreover, when dealing with major innovations, not only the institutions shaping production relationships must be altered but also the way the sector organizes innovation, i.e. the innovation system itself must change.
\end{abstract}

Keywords: Coastal fishing; systems of innovation; institutions.

'ICEDE Research Group, University of Santiago de Compostela, Facultade de Económicas e Empresariais, I5782 Santiago de Compostela Galicia - Spain, Ph: +34 98I563I00 (I I57I):Email: manuel.gonzalez.lopez@usc.es 
J. Technol. Manag. Innov. 20II,Volume 6, Issue 3

\section{Introduction}

This paper explores into the relationship between institutions and innovation. Institutions are understood as formal or informal arrangements that govern the relationships among agents. For this reason institutions are usually considered a key component of innovation systems (Edquist, 200I). It is said that institutions favor innovation because they give rise to the necessary stability for fluid knowledge exchanges and learning processes (Carlsson and Jacobson, 1997). Nevertheless, at the same time, to innovate implies to break or alter routines and behaviors, i.e. to alter institutions (Nelson and Winter, 1982; Granovetter, 2002). Therefore we could say that a contradictory relationship between institutions and innovations exists. Although some authors like Grabher (1993) have referred to this apparent contradiction, more research is needed in order to clarify the ways through which institutions affect innovation. Our objective is precisely to shed some additional light on the apparently contradictory relationship between institutions and innovation.

We will analyze the innovation system of the coastal fishing sector in Galicia, a region of Northwest Spain, trying to find out which agents, interaction and institutions shape the innovative processes in the sector. This will be a previous step towards a subsequent discussion on how two major institutions governing the relationships in this system are affecting the innovation process. The paper is structured as follows: firstly, and after a brief introduction of the innovation system approach, we discuss the relationship between institutions and innovation based on the existing literature. Later we present a short description of the coastal fishing sector in Galicia. We then continue with the analysis of the coastal fishing innovation system by first presenting the innovation performance of the sector and then by giving an account of the main channels for innovation and knowledge incorporation in the sector. In the following sections we enter into the description and consequences of the institutional arrangements that govern two key interactions within the system: the ones linking the sector with the regional government and the ones connecting fishermen with their clients (fish intermediaries). Finally some conclusions are raised with the main findings of our research.

\section{Innovation systems and institutions}

\section{I. Innovation systems}

The works published by Lundvall (ed) (1992) and Nelson (ed) (1993) can be considered as the starting point of the Innovation System approach. The initial focus was on the national specificities shown by the innovation process, i.e. how innovation differs across countries due to differences on the institutional, organizational and other structural factors. According to Edquist (1997) the innovation system literature rests on two major theoretical corpora. One of them is the post-schumpeterian stream known as the Evolutionary School (Nelson \& Winter, 1982; Dosi, 1988; etc). Evolutionary advocates emphasize, like Schumpeter did, the dynamic character of the economy in contrast with the Neoclassical focus on equilibrium. This dynamic character is highlighted by new combinations of productive factors (innovations). Besides, innovations are pathdependent, i.e. they are determined by previous changes in technologies and -in broad terms- in the economic structure. That would explain why each sector or territory follows different innovation trajectories shaping different innovation systems. The other theoretical source of the innovation systems approach is the so-called "interactive learning theories". These theories understand innovation as a ubiquitous phenomenon that is product of multiple and continuous learning processes where multiple agents participate. Thus, interactions between users and providers of technologies and products are relevant for innovation (Lundvall, 1988). Interactions between the staff of companies, between universities and firms, etc are also relevant.

Institutions are usually understood as a key component of an innovation system (Edquist, 200I; Doloreux, 2002; etc). Edquist and Johnson (1997) define institutions as "sets of commons habits, routines, established practices, rules, or laws that regulate the relations and interactions between individuals and groups". Institutions, according to the referred authors, can be formal (such as laws and regulations) or informal (like cultural norms and habits). Considering this definition, institutions enter into the innovation system approach because they "govern" the relationships among the agents of the system. 


\subsection{The Institutions-Innovation dilemma}

A contradictory relationship between institutions and innovation can be reported according to the existing literature. Thus, Carlsson and Jacobson (1997) point out that institutions stimulate innovation because they reduce uncertainties, coordinate the use of knowledge, mediate conflicts, and provide incentives. Nevertheless, because of its nature, to innovate implies also to alter existing routines, habits and even legal frameworks (Nelson and Winter, 1982, Ganovetter, 2005). I.e. institutions favor the innovative process but, at the same time, innovation implies changes affecting institutions.

Both the Institutional Economics and the Economics of Innovation literature have directly or indirectly referred to the relationship between institutions and innovation. Douglas North (1994) has argued about the nature of economic change pointing out that whilst most of the time it is a matter of decisions based on existing routines and institutions, some changes can imply the alteration of such routines. These decisions "involve altering existing "contracts" between individual and organizations. Sometimes that recontracting can be accomplished within the existing structure of property rights and political rules, but sometimes new contracting forms require an alteration in the rules. Equally, norms of behavior that guide exchanges will gradually be modified or wither away. In both instances, institutions are being altered” (North, 1994, 36I). We could interpret from North's words that although some innovations are made within the existing institutional framework, others imply the alteration such framework.

Grabher (1993) delves deeper into the previous argument whilst, however, referring to social networks instead of institutions. According to Grabher the relationships among economic agents are embedded in, and shaped by, social networks (which for our purposes can be understood as informal institutions). These social networks act positively regarding incremental innovations, but "with respect to major change, however, the role played by the social embeddedness of networks is not clear" (Grabher, 1992, 24). The author raises here the concept of the "embeddedness dilemma" pointing that "too little embeddedness may expose networks to an erosion of their supportive tissue of social practices and institutions. Too much embeddedness, however, may promote a petrification of this supportive tissue and, hence may pervert networks into cohesive coalitions against more radical innovations" (Grabher, 1993, 26).
From Grabher arguments we could therefore learn that, when dealing with major innovations, institutions may act as a barrier to innovate. This is because these innovations would probably also require radical changes in institutions. This role of institutions as constraints for innovations has also been stressed by David (1993): "the historical context in which institutions or organizations are formed, can become enduring constraints. They can result in the selection of a particular solution for what is then perceived at the time to be the crucial generic function" (...) In this way the organizational structure can become "locked in" to a comparatively narrow subset of routines, goals and future growth trajectories" (David, 1993, 214). In fact institutions are many times more difficult to change than technologies: "institutions generally turn out to be considerably less "plastic" than is technology and the range of diversity in innovations achieved by recombinations of existing elements is observed to be much broader in the case of the latter" (David, 1993, 218).

In similar terms, Lindkvist \& Sánchez (2008) have discussed the relationship between innovation and institutions, although referring to "conventions" (nonformal institutions). The authors referred particularly to natural resource based industries and they point out that those industries that have been successful usually showed an adaptive behaviour of their conventions to new contexts. Nevertheless, other industries were less success precisely because of the rigidity of the existing conventions. As pointed out by these authors: "market success or failure depends on the collective ability of local actors to restructure the sect of conventions, to reduce the influence of domestic and industrial conventions, and to become more open to market variations and public intervention" (Lindkvist \& Sanchez, 2008, 353).

The contradictory relationship between institutions and innovations has also been approached from a perspective that focuses on knowledge exchange between economic actors. Thus, Boschma (2005) has referred to this issue pointing out that actors sharing the same institutional framework might be less permeable to new knowledge but, on the contrary, different institutional backgrounds act as barriers for new ideas. As indicated by the author "too much institutional proximity is unfavorable for new ideas and innovations due to institutional lock-in (obstructing awareness of new possibilities) and inertia 
(impeding the required institutional readjustments). On the other hand, too little institutional proximity is detrimental to collective action and innovation due to weak formal institutions and a lack of social cohesion and common values" (Boschma, 2005, 68).

Therefore, based on the existing literature we can schematize the relationship between institutions and innovations saying that there is a contradictory relationship between innovation and institutions, an institutionsinnovation dilemma. Institutions boost innovation because they reduce uncertainties and allow the necessary stability for fluid knowledge exchanges and learning processes. This applies particularly to incremental or routine innovations. Nevertheless, when dealing with major innovations, institutions might act as a corset for innovation. In this case, for innovation to occur, most of the time, an institutional change is needed (and this is not an easy question).

In the following paragraphs we aim at adding to this issue trying to clarify in which conditions a given institutional framework may foster innovation or, on the contrary, hinder it. For this purpose we have analyzed the case of a particular sector, the coastal fishing sector in Galicia (Spain).

\section{The coastal fishing sector in Galicia: a brief introduction}

Galicia is one of the EU regions with highest dependence on fisheries. Moreover, the Galician high seas fishing fleet is one of the most important fishing fleets of the European Union. Nevertheless, like in many other coastal regions, while high seas fishing became modernized and integrated into transformation and marketing channels, coastal fishing remained unfamiliar to many technical, organizational and productive changes. We deal with a traditional and largely artisanal fishing fleet in coastal zones.

Despite its lack of modernization, coastal fishing still has considerable economic importance in the Galician economy and particularly in coastal towns. According to the most recent official statistics, direct employment in this sector reaches 10,716 people in 2004, around I\% of the region's total employment. Moreover, the (declared) business turnover of the sector reaches $€ 221.17$ million in 2004 which, only for contextualizing purposes, was equivalent to $0.5 \%$ of the Galician GDP that year (IGE, 2004).

\section{I. Sector organization: the key role of "confrarías" (fishermen's associations)}

The organization of production in the coastal fishing sector shows some particular features that need to be explained. The sector is formed by small (family) firms that generally own one vessel where between $I$ and 3 people are employed. These firms group themselves in "confrarías", professional associations with a strong historical tradition in Galicia and other parts of Spain. There are 62 "confrarías" in Galicia grouping 4,247 vessels specialized on coastal fishing (Pescadegalicia, 2009).

Fishermen associations have a particular nature since, whilst formed by professionals with profit interest, they are legally dependent on the regional government. According to current legislation, "confrarías" have two major functions: on one hand they perform as an administrative body that collaborates with the regional government; on the other they look for "the defense of their professional interests". Production orientation and organization activities are included in this second function since the approval of the "Confrarías Law" in 1993.

\subsection{The fishing commercializing system}

Another particular characteristic of the coastal-fishing sector refers to the commercializing system. According to Allut and Freire (2002) we are dealing with a wide and complex process that has decisive effects on the fishing activity. The referred authors indicate that the sale system gives rise to strong uncertainties in the agent's behavior (fishermen and "confrarías"). Such uncertainties would be explained by:

- Natural factors restrictions, basically biologic and climatologic ones. They have an effect on fishing production since they make the prediction of captures difficult. This results in both price and working hours fluctuations, with the subsequent effects on fishermen incomes.

-The perishable nature of fish that forces fishermen to put it quickly into circulation. The greater the delay between capturing and selling, the lower the sale price will be.

-The first sale system configured as "stop-out price" auction. This particular system takes place in fish markets managed by fishermen's associations and in practice means a split between producer and product. This is 
because of the key role of first buyers or intermediaries that work in each of the 62 fish markets of Galicia. In most of these markets, particularly in the smallest ones, the intermediaries hold a "monopsony" position in such a way that they force prices down for their profit.

According to Allut and Freire $(2002,12)$ when referring to the previous point: "if, on top of the variable character of fishing (capture unpredictability), we add the particular auction system, we obtain a new argument revealing the difficulties of fishermen to capitalize their sector". I.e., the uncertainties coming from natural and economic factors (sale system) would explain the sector underperformance in capital accumulation and therefore difficulties for its modernization.

Moreover, the consequences go further and give rise also to environmental and sustainability problems. Thus, when low prices predominate for a long time fishermen usually react by increasing captures in order to maintain their income (which in the short term results even in lower prices!). This behavior leads to an increasing pressure on natural resources challenging the long-term sector sustainability. The consequences of this negative impact are corroborated by some studies like the one made by Villasante (2009), that points to a situation of overfishing in the Galician continental platform.

\section{Innovation performance of the coastal fishing sector in Galicia}

We present hereafter the main results of an empirical analysis conducted in order to comprehend the functioning of the coastal fishing innovation system. Our analysis rests on an exhaustive in-field research where information was collected by two means. Firstly, a questionnaire was sent to all fishermen's associations in the region. Fifty-seven questionnaires were sent obtaining a feedback of 25 correctly filled in questionnaires (representing a response rate of $40.32 \%)$. Secondly, interviews with persons in charge of managing activities in fishermen associations were carried out. Ten interviews were carried out once the questionnaire was filled in, and by this means we obtained more accurate information and some points of the questionnaire were clarified. Finally, two workshops with sector agents were developed where the provisional findings of our research were presented.
Like in any other economic activity, innovations in coastal fishing are diverse in their nature and scope. For this reason and for analytical purposes, a taxonomy of innovations for this sector was used. Following the previous analysis of innovation in fishing activities (Cetmar \& OPI, 2005), we have considered four different innovation fields in the coastal fishing sector: extractive, manufacturing, commercialization and organizational and resource management. We must point out that innovation is understood here as any change with a productive, commercial or organizational effect that takes place in firms or fishermen associations.

\section{I. Innovations in the extractive field}

The sector was quite active when dealing with innovations in the extractive process. Innovations refer here to the incorporation of information and communication technologies (ICT) in fishing vessels, new or improved industrial safety related technologies or improvements in vessels (engines, materials, fuel, etc). More than $70 \%$ of the associations innovated in any of these fields during the last five years. The public sector is indirectly responsible for a good part of innovations in this field since in some cases, like ICT or industrial safety, the motivation for innovating has to do with the need to comply with public norms and regulations. In the case of vessels improvements the role of the public sector is a financial one, since many innovations are partially financed by means of public programs.

\subsection{Innovations in the manufacturing field}

Unlike the extractive field, innovations in processing are very poor (actually they are inexistent in most fishermen's associations). The sector's involvement in processing activities has traditionally been nil and it seems that the situation has not changed recently. Innovations are related to the participation of just a few associations in establishing processing companies and to some improvements in packing systems ( $4 \%$ in the first case, $8 \%$ in the second one).

\subsection{Innovations in the commercializing field}

Regarding the commercializing sphere the fishermen's association seem to be a bit more active than the previous field but, in any case, not too dynamic. Introducing product brands together with other marketing activities are the most common innovations in such a way that around 30\% 
of the "confrarias" developed it. Some of these initiatives have to do with the government initiative of promoting a brand for Galician coastal fishing ("Pesca de rias") still in early stages of development. Moreover around $20 \%$ of "confrarias" participated in the establishment of companies for fish commercialization, some of them using internet platforms. Some innovations have also been taking place at the fish markets managed by the fishermen associations; they refer to the introduction of ICT like electronic auction systems, etc. These improvements are usually funded by the regional government.

As mentioned before, fishermen are rarely involved in commercializing activities. Nevertheless when asked about future trends they usually point to this area among the most critical ones. Many of the associations understand that they need to be more involved in commercializing in order to increase fishermen incomes, nonetheless -as we will see later- there are barriers impeding changes in this area.

\subsection{Innovations in the organization and resource management field}

Fishermen's associations were also asked about innovations in both the organizational and resource management spheres. Regarding the organizational field, around one third of associations introduced some kind of changes in their internal organizational forms. In some cases changes targeted increasing management and business skills in the associations by means, for instance, of establishing the figure of the "fishermen association manager". This kind of innovations might result in being of great importance since innovations in other fields can be undertaken only after organizational changes are introduced.

Finally, slightly less than $40 \%$ of the associations innovated in the resource management field. Innovations referred to new or improved methods for the management and exploitation of commercial species. In this sense we should mention the key importance of "exploitation plans" that were promoted by the regional government at the beginning of the 90 s, particularly for shellfish species like goose barnacle, a highly valuable seafood product in European markets. These plans aim to control the level of captures (quantities, fishing seasons, etc) and were introduced mainly for environmental reasons (to avoid resources over-exploitation). Besides, some associations have launched plans for specific species apart from the ones approved by the regional administration. Another innovation is the establishment of marine reserves, but the ones introduced (two) are still in a pilot scheme.

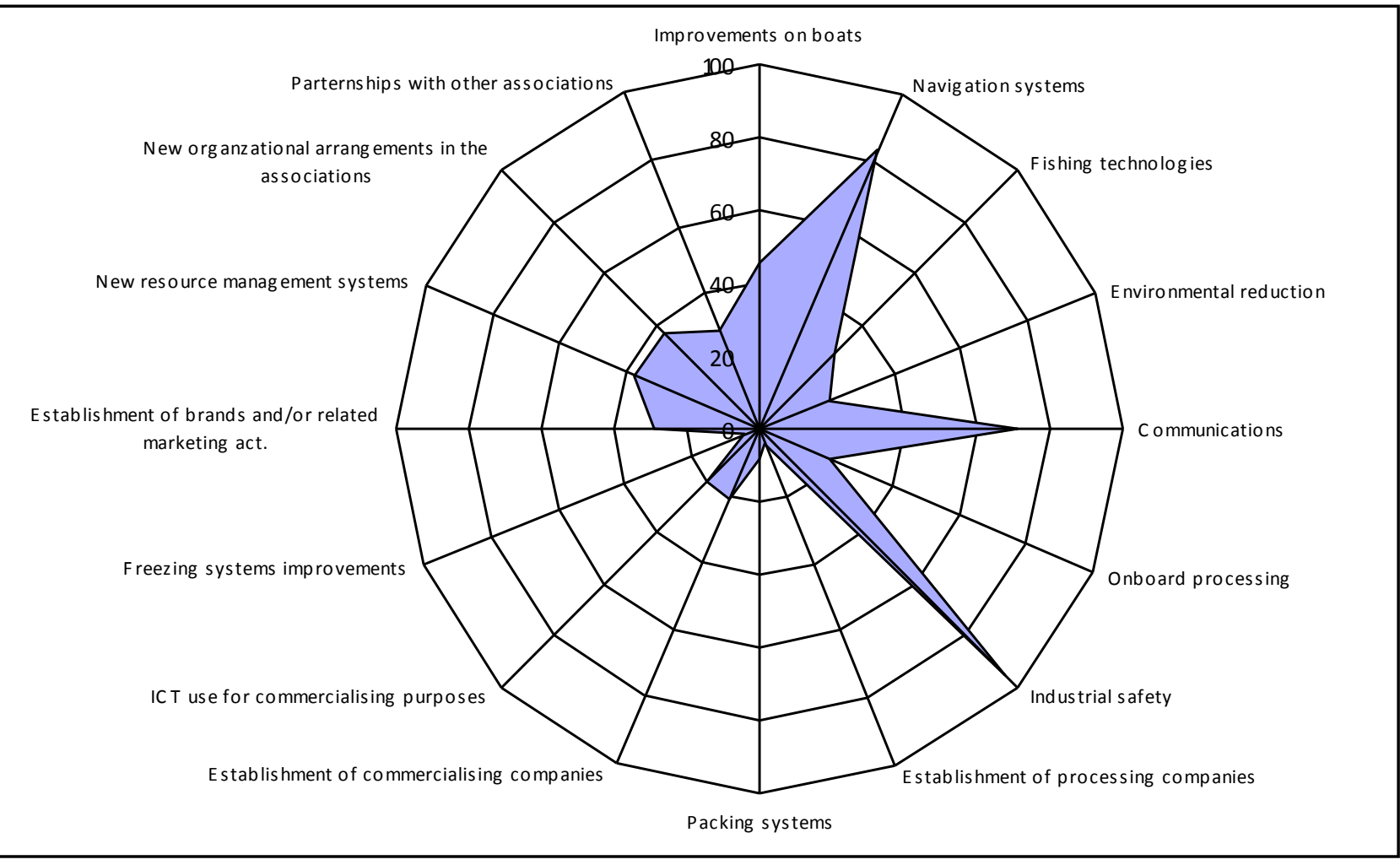

Figure I. Innovation performance (\% of associations innovating in each field) / Source: Own-elaboration from questionnaire data. 
Therefore, from the analysis of the innovative activity in fishermen's associations we can conclude that this was mainly pursued in the extraction process and, to a lesser extent, in the organizational and resource management fields. Furthermore innovations are very poor or inexistent when dealing with processing and commercial issues. In fact, the information obtained reflects that the sector is rarely involved in the processing and commercializing sphere. Later on we will try to put some light on this question.

\section{Learning processes: channels for innovation and knowledge incorporation}

Fishermen associations were asked about the channels through which they incorporate knowledge and innovate. In doing this, we aimed firstly at understanding the sector's attitude towards innovation and, secondly, which interactions and agents play a role in the innovation system.

First of all, the information obtained indicates that none of the fishermen's associations undertake internal R\&D activities. Furthermore activities that usually imply an active involvement in innovation like joint projects with universities or technological centers are rarely used.

Moreover, the most used channels for innovating and incorporating knowledge are, generally speaking, those ones where fishermen's associations show a passive role. We refer to the purchase of machinery and fishing tackle, training or informal contacts with providers, clients and personnel from other associations. Machinery and fishing tackle purchase is actually the most used channel for incorporating knowledge. Attending to the traditional classification proposed by Pavitt (1984), this sector could hence be labeled as a "supplier-dominated" one. Coastal fishing suppliers can be divided into those providing inputs to individual firms and others that sell their products to the fishermen's associations. In the first case we deal with the ones selling vessels, fishing tackle, ICT products, etc. There is a long tradition of fish specialized providers and, for instance, there is consolidated shipyard industry in the region (with a wide range of specialization regarding size, productive aim, etc). With regard to the fishermen's associations suppliers they basically provide machinery for fish classification, scales, etc. The associations have also been incorporating ICTs like electronic auction systems as well as common technologies for administrative and management tasks (specific software, internet...).
On the other hand, hiring specialized services from universities and consultancies as well as innovative projects with other fishermen's associations were used by roughly half of the associations. Some of these channels are related to the commercializing and resource management spheres. Thus, when dealing with commercializing, the sector's historically poor involvement explains its lack of knowledge in that field and for this reason, in order to innovate, they usually need external support. Understandably associations innovating in this sphere usually hired specialized services from universities or consultancies.

Finally, innovations in the resource management field are the ones most commonly related to scientific knowledge coming from universities and public research centers. We should point out here the importance of a program funded by the regional government in order to incorporate biologists to the fishermen associations. Biologists are in charge of control activities related to fish stocks conservation, scientific assessments, etc. At the same time, since many of these biologists came from the academic field, this helped the creation of linkages between universities and the sector. 


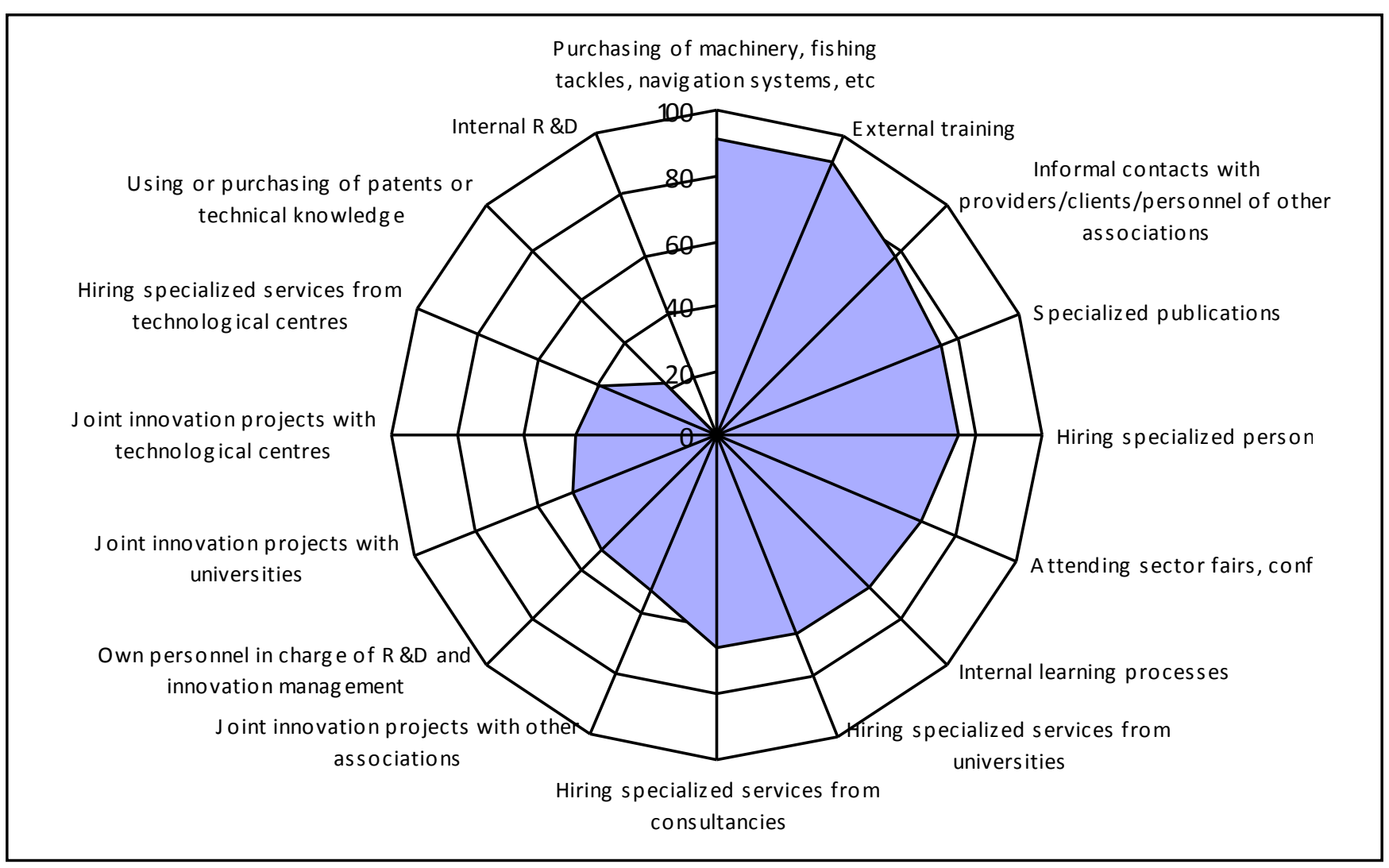

Figure 2. Channels for innovation and knowledge incorporation (\% of associations using each) / Source: Own-elaboration from questionnaire data.

\section{Innovation in coastal fishing: An administra- tion-dominated sector}

The Galician autonomous government is a key agent in the coastal fishing innovation system. In fact, as has already been pointed out, fishermen's associations are legally dependent upon the regional government and hence relationships between them are particularly close. The interactions between the sector and the government take two major forms: regulation and financing. On one hand, the regional government establishes the sector's legal framework, from general aspects (the Fish Law or the Fishermen Associations Law) to key specific ones (exploitation plans). On the other hand, the public administration contributes to the sector's financing by means of regular funds for association's bureaucratic activities, technical personnel like biologists, etc; and also with specific programs aimed, for instance, at fleet modernization, fishermen's training, etc. As a matter of fact, the regional government is the main external financing source of the sector since relationships with the banking sector are quite poor.
Therefore the sector's narrow relationship with the government is in many aspects positive for the sector innovation. This institutional network brings funding for investments, favors coordinated action and provides stable channels for incorporating knowledge to the sector. To some extent the government's role also helps to overcome the small size of fishermen firms and associations that is, according to the information collected from the sector, one of the main barriers for innovation.

However, this dependence on administration could also be acting as a barrier for innovation. First of all, the fact that fishermen's associations are legally dependent on regional government has sometimes been an obstacle for innovating in key aspects because of legal rigidities. For instance, the productive and professional nature of fishermen associations was only explicitly recognized after the publication of the Galician Fishing Law, in 1993. Furthermore, the legal figure of the fishermen's association managers was not recognized before this law. In the same way, direct commercializing to final customers was not 
permitted to fishermen's associations until the publishing of the law. Nevertheless there are probably some more serious consequences related to such dependence from the government: it gives rise to accommodating and passive behaviors by the sector agents. This is shown, for instance, when dealing with investments and innovations funding. According to the opinion of most of the interviewed persons, the common use of public funding implies a poor risk culture; agents rather risk public money than their own. At the same time, in the field of resource conservation, the "authority" role of public administration hinders the sector's responsibility in this regard. Although some changes have occurred in previous years, even today fishermen protests are not unusual when the administration establishes closed seasons for some species.

The relationship between this sector and the public government could therefore be considered as an example where an institution (taking a formal and informal form) may play, at the same time, a positive and a negative role on innovation and change. Besides, this can apply indistinctly to incremental and major innovations. Thus, together with incremental innovations, some major innovations like the establishment of exploitation plans have been possible thanks to governmental action and its close relationship with the sector. Nevertheless, amongst other factors, the excessive dependence on government hinders the possibilities of raising an endogenous risk culture and that acts as a barrier for major changes in the sector.

\section{Barriersto changedueto the commercializing process particularities}

As indicated before, the sector is decisively affected by the particularities of the commercialization process that, at the same time, is affected by natural factors (weather conditions, biological cycles, etc). Innovations, as well as investments, are easier with stable economic scenarios and these can hardly be obtained when the sector agents hold little control on prices or outputs levels. This is one of the reasons explaining the sector's low levels of capitalization as well as poor performances on innovations. Fishermen's associations could make up for this lack of capitalization and to some extent they already do it. Nevertheless this is not enough to improve innovation performance in fields like processing or commercializing. The problem is largely due to the impossibility of changing the traditional commercialization system. Thus, innovating in this field implies that the monopoly position of first buyers (intermediaries) must be altered or broken. That increases the risks of launching initiatives where fishermen associations directly commercialize their fish since they are disapproved by intermediaries and can be boycotted. There is also an endogenous resistance related to fishermen's fears towards the introduction of changes in this system. One of these fears regards the way fishermen are paid by intermediaries, usually on a daily or weekly basis. This routine works as a barrier to undertake projects for direct commercializing, among other reasons, because those projects usually imply dealing with buyers like supermarket chains that pay after a longer period (one, two or even three months). Of course this barrier could be overcome by means of common external financing but fishermen's associations, because of the reasons discussed in the previous point, are not used to it.

Moreover, thesplitbetween productionandcommercializing has another important effect that could be acting as a barrier for sector change. Thus, since fishermen do not have any involvement with commercializing issues they can not "know" anything about this process. Intermediaries are the ones owning the required knowledge in this field and, to a great extent, their benefits come from the monopolization of such knowledge. There is hence a barrier to information and knowledge exchange between buyers and producers that may impede learning process in the sector. In this scenario, formal interactions between fishermen and their direct clients (intermediaries) for innovative purposes, in the form of collaborative projects or others, do not exist. There are only informal contacts that do not seem to have relevant consequences due to the reasons presented above. In fact, the associations that have innovated in this field have also "innovated" in the channels used to incorporate knowledge. They either established collaborative agreements with universities and technological centers or hire professional services from consultancies and other organizations.

Therefore, we are dealing here with a market-related institutional barrier for change and innovation in the sector. Following authors like North (1994), Grabher (1992) and others, this seems a case of institutional lock-in and inertia that needs a rupture of traditional ways of doing things in order to innovate. Resistances are both endogenous and exogenous although in this case the latter seems to be more important. An institutional change here means an alteration of the status quo in the market power distribution and this becomes a hard task to be accomplished. 


\section{Conclusions}

Institutions play a central role in innovation because they shape the interactions between the agents participating in the processes of learning and knowledge creation in sectors and territories. Based on the existing literature we can affirm that there is an institution-innovation dilemma. Thus, institutions boost innovation because they reduce uncertainties and allow the necessary stability for fluid knowledge exchanges and learning processes. This applies particularly to incremental or routine innovations. Nevertheless, some authors have indicated that when dealing with major innovations, institutions might act as a corset for innovation. In this case, for innovation to occur, most times an institutional change is needed (and this is not a easy question).

In this paper we have tried to add to this dilemma by pointing out that a given institutional arrangement can play a positive and a negative role on innovation and change. Besides, this can apply indistinctly to incremental and major innovations. This is the case of the institutional set-up (that takes a formal and informal nature) governing the relationship between the coastal fishing sector and the public administration in Galicia. Thus, together with incremental innovations, some major innovations like the establishment of exploitation plans have been possible thanks to governmental action. Nevertheless, among other aspects, the excessive dependence on government hinders the possibilities of raising an endogenous risk culture in the sector.

Moreover, institutions and conventions might be, as pointed out by the literature, a barrier for major innovations in a sector. This happens for instance when innovation implies the alteration of the market power status quo among interrelated economic agents. This is the case of many market based institutional interactions like the ones shaping the relationships between fishermen and their clients: the intermediaries. When this happens not only the status quo needs to be altered but the innovation system itself must be changed. In our case, the few associations trying to innovate in the commercializing field needed knowledge that did not come from the existing agents of the system but from new ones like universities, technological centers and consultancies. Nevertheless the effort is still not enough in terms of the sector as a whole. Time will tell whether this is the beginning of a new institutional arrangement for the sector or not.

\section{References:}

ALLUT, A. \& FREIRE, J.M. (2002); "Procesos de producción pesquera e incertidumbre: La comercialización de los productos pesqueros en la pesca artesanal de Galicia”. Andar o Mar, II Xornadas Internacionais de Cultura Tradicional. Asociación Canle de Lira.

BOSCHMA, R. (2005); "Proximity and innovation: a critical assessment”, Regional Studies 39, 6I-74.

CARLSSON, B. \& JACOBSSON, S. (1997); “Diversity creation and technological systems: a technology policy perspective" in EDQUIST , C. (1997); Systems of innovation: technologies, institutions, and organizations. London: Pinter Publisher.

CETMAR \& OPTI, (2005); El futuro de la tecnología de la pesca. Centro Tecnolóxico do Mar e Fundación OPTI.

CORIAT, B. \& DOSI, G. (2000); "The institutional embeddedness of economic change: an appraisal of the "evolutionary" and "regulationist" research programmes". In Dosi, G. (2000); Innovation, organization and economic dynamics. Gletenham: E. Eldgar.

DAVID, P. A. (1993); "Why are institutions the "Carriers of History"?: Path Dependence and the Evolution of Conventions, Organizations and Institutions" Structural Change and Economic Dyanamics. Vol. 5 N. 2. 205-220.

DOLOREUX, D. (2002); “What we should know about regional systems of innovation" Technology in society. 24 (2002) 243-263.

DOSI, G. et al (1988); Technical Change and Economic Theory. London: Printer Publishers.

EDQUIST, C. (1997); "Systems of Innovation Approaches - Their Emergence and Characteristics" in EDQUIST, C. (1997) (ed); Systems of innovation: technologies, institutions, and organizations. London: Pinter Publisher.

EDQUIST, C. (200I); "The system of innovation approach and innovation policy: an account of the art of the state of the art". Paper presented at the DRUID Conference, Aalborg, June 12-15, 2001. 
EDQUIST, C. \& JOHNSON, B (1997); "Institutions and Organizations in Systems of Innovation" en EDQUIST, C. (1997); Systems of innovation. Technologies, Institutions and Organizations. Oxon: Pinter.

GRABHER, G. (1993); The embedded firm. On the socioeconomics of industrial networks. Routledge: New York.

GRANOVETTER, M. (2005); "The impact of social structure on Economic outcomes". Journal of Economic Perspectives. 19, I, 35-50.

IGE (2004); Sistema de Contas. www.ige.eu

LINDKVIST, K \& SÁNCHEZ, J. (2008); "Conventions and innovation: a comparison of two localized natural resource-based industries" in Regional Stuides, Vol. 42,3, 343-354.

LUNDVALL, B.-Å. (ED.) (1992). National System of Innovation: Towards a Theory of Innovation and Interactive Learning. London: Pinter Publisher.

LUNDVALL, B- $\AA$ (1988); “Innovation as an interactive process: from user-producer interaction to the national system of innovation" In: Dosi, G., et al. (Eds.), Technical Change and Economic Theory. Pinter Publishers, United Kingdom, pp. 349-369.

MALERBA, F. (2002); "Sectoral systems of innovation and production" Research Policy 31 247-264.

NELSON, R. \& WINTER, S.G. (1982); An evolutionary theory of Economic Change, Cambridge: Harvard University Press.

NELSON, R.R (Ed.). (1993). National innovation systems: a comparative analysis. Oxford University Press, New York.

NORTH, D. (1994); "Economic performance through time" The American Economic Review. Vol. 84, No. 3 (Jun., 1994), pp. 359-368.

PAVITT, K. (1984). "Sectoral patterns of technical change: towards a taxonomy and a theory". Research Policy 13: 343-373.

PESCADEGALICIA (2008); Estatísticas. www.pescadegalicia.com Xunta de Galicia.
VILLASANTE, S. (2009); “A pesca artesanal en Galicia e o fenómeno de "fishing down marine food webs". Departamento de Economía Aplicada: USC (inédito). 
J. Technol. Manag. Innov. 20II,Volume 6, Issue 3 